\title{
Active genes in budding yeast display enhanced in vivo accessibility to foreign DNA methylases: a novel in vivo probe for chromatin structure of yeast
}

\author{
Jagmohan Singh and Amar J.S. Klar \\ NCI-Frederick Cancer Research and Development Center, ABL-Basic Research Program, Laboratory of Eukaryotic Gene \\ Expression, Frederick, Maryland 21702-1201 USA
}

\begin{abstract}
Unlike higher eukaryotes, where an inverse correlation has been generally observed between gene expression and methylation of $\mathrm{CpG}$ sites, the budding yeast Saccharomyces cerevisiae lacks DNA methylation. Gene regulatory mechanisms can function independently of DNA methylation in yeast, and yeast strains expressing foreign DNA methylases that modify adenine and $\mathrm{CpG}_{\mathrm{P}}$ residues have been found to be viable. We have used such strains to determine whether the transcriptional status of genes can influence the level of their DNA methylation in vivo. Several genes were tested, for example, GAL1, -7, and -10, PHO5, HMRa and $H M L \alpha$, and STE2 and STE3. Surprisingly, we found that all the genes displayed severalfold more methylation in the expressed state as compared to the repressed state. This procedure serves as a novel in vivo probe for the chromatin structure of yeast and potentially for higher eukaryotes.
\end{abstract}

[Key Words: In vivo DNA methylation; gene expression; budding yeast; foreign methylases]

Received November 25, 1991; revised version accepted December 30, 1991.

The budding yeast Saccharomyces cerevisiae and higher eukaryotes share several common features of chromatin structure, including nucleosomal organization, folding of chromatin into higher-order structures, as well as the conservation observed for transcriptional machinery (Weintraub 1985; Guarente 1988; Lowary and Widom 1989; Perez-Ortin et al. 1989). Although the budding yeast is thought to lack $\mathrm{Hl}$ histone (Perez-Ortin et al. 1989), a functional $\mathrm{Hl}$ homolog was demonstrated recently (Lowary and Widom 1989). In addition, active genes in yeast and higher eukaryotes display similar functional features, i.e., enhanced sensitivity to singlestranded endonuclease S1 and DNase I at sites flanking the active genes (for reviews, see Weintraub 1985; PerezOrtin 1989), indicating an alteration of nucleosomal organization in the promoter and coding regions upon gene activation.

Despite these similarities, yeast and higher eukaryotes differ in one major respect: higher eukaryotes display methylation of cytosine residues in the $\mathrm{CpG}$ sequences in DNA (Holliday and Pugh 1975; McGhee and Ginder 1979; Cedar 1988; Razin and Riggs 1980; Felsenfeld and McGhee 1982; Holliday 1987), whereas the budding yeast is shown to lack this modification (Proffitt et al. 1984). More importantly, an inverse correlation has generally been observed between $\mathrm{CpG}$ methylation and gene expression in vertebrates and plants, leading to the hypothesis that gene expression is regulated by cytosine methylation in higher eukaryotes. Because DNA methylation does not exist in yeast, mechanisms of gene activation and repression in yeast must operate independently of DNA methylation. Expression of the Escherichia coli dam methylase, which methylates adenine residues in GATC sites, and Bacillus subtilis SPR phage cytosine methylase, which methylates the cytosine residues in the HpaII (and also HaeIII and BstNI) sites, do not confer lethality to yeast (Hoekstra and Malone 1986; Feher et al. 1988).

As a way to monitor chromatin changes directly in vivo, we have exploited the yeast system by expressing foreign DNA methylases. We tested whether the transcriptional status of a gene modulates the level of methylation. We found that transcriptionally active loci are methylated more efficiently in their promoter and coding regions than are inactive genes. Thus, methylation of DNA in chromatin, especially by dam methylase, can be used as a novel and powerful probe for studying alterations in chromatin structure. This novel experimental approach should supplement the DNase I mapping technique and also be potentially applicable to the study of chromatin structure in higher eukaryotes.

\section{Results}

In the first set of experiments, we used yeast strains in which the E. coli dam methylase gene was chromosom- 
ally integrated at the $U R A 3$ locus (Hoekstra and Malone 1986) and expressed under the control of the bacterial promoter. Thus, the adenine residue in GATC sites in chromatin is methylated. In the second set of experiments, the gene for the $B$. subtilis SPR phage cytosine methylase was expressed in yeast strains (Kiss and Baldauf 1983; Feher et al. 1988). Previously, it was noted that radiation-sensitive (rad3-2) mutant strains, which are defective in DNA excision repair, have $20-30 \%$ higher levels of DNA methylation than $R A D 3^{+}$strains, presumably because the excision-repair pathway in $R A D 3^{+}$strains removes the $\mathrm{N}^{6}$-methyladenine and 5-methylcytosine residues (Hoekstra and Malone 1986; Feher et al. 1988). Therefore, rad3-2 strains were employed in this study.

\section{dam methylation of the GAL1-10 divergent promoter}

The transcriptional activity of GAL1 and GAL10 genes, whose expression is under the control of the GAL1-10 divergent promoter (Johnston and Davis 1984), can be altered by the kind of sugar used for growth of yeast culture. These genes are repressed by glucose, highly induced by galactose, or potentially active in raffinose medium. The potentially active state is defined as lacking a lag period in induction upon addition of galactose to the raffinose-grown cells. Methylation of Sau3AI (GATC) sites was quantitated by digesting the purified DNA with $M b o I$ and $D p n I$. MboI digests only unmethylated GATC sites, and DpnI only dimethylated sites (methylated on both strands), whereas Sau3AI cleaves irrespective of methylation.

The extent of dimethylation of a unique Sau3AI site, located $15 \mathrm{bp}$ upstream of the TATA box and within the essential GAL promoter region (Johnston and Davis 1984) in the EcoRI-AvaI fragment (Fig. 1A), was estimated from the fraction of the $0.85-\mathrm{kb}$ fragment digested by $D p n I$. It was found to be $3.5,45.0$, or $3.5 \%$, respectively, for cells grown in glucose, galactose, or raffinose (Fig. 1B, lanes 4, 8, and 12, respectively). Thus, an increased level of dimethylation occurred in the expressed state. The $M b o I$ digestion pattern (lanes 3, 7, and 11) also supported this conclusion. The fact that $M b o$ c cuts only unmethylated and not hemi- and dimethylated DNA allows a direct quantitation of the level of hemi- and dimethylation. The level of hemimethylation was estimated by subtracting the level of dimethylation estimated from $D p n I$ digests from that of hemi- + dimethylation obtained from $M b o I$ digests. Interestingly, a similar level of hemimethylation (Table 1) was observed for growth in glucose $(24 \%)$, raffinose $(25 \%)$, and galactose $(27 \%)$. Thus, the significant increase is observed only for dimethylation in expressed state.

Methylation of the second Sau3AI site located in the GAL1 coding region (Fig. 1A) was also investigated. This Sau3AI site overlaps the $\mathrm{XbaI}$ site in the sequence $5^{\prime}$ TCTAGATC-3', whose digestion with $\mathrm{XbaI}$ is blocked by methylation of the Sau3AI site. As judged by the fraction of the $1.91-\mathrm{kb} E c o$ RI fragment remaining uncut by
$X b a$ (Fig. 1C), the Sau3AI site in the GAL1 coding region was methylated (hemi- + dimethylation in this case) six- to ninefold more in DNA isolated from cells grown in galactose (lane 2) than in glucose (lane 1) or raffinose (lane 3). Thus, sites located both in the coding and the promoter regions (as well as several other sites in the GAL1 coding region; data not shown) are methylated at an increased level in expressed state.

In principle, a slower growth rate of cells in galactose medium may allow dam methylase to act for a longer time in each cell cycle, providing a trivial explanation for the observed higher level of methylation. However, this possibility is unlikely because the generation time was quite similar in medium containing glucose (101 min), raffinose $(114 \mathrm{~min})$, or galactose $(120 \mathrm{~min})$ (data not shown). Furthermore, when the $G A L$ genes were induced by independent genetical means, the active genes again displayed increased levels of methylation, as shown below.

These results indicated that GAL1-10 chromatin is more accessible to dam methylation in its expressed state than in its unexpressed state. If this is indeed the case, then a higher level of methylation should be expected in strains allowing expression by other means. For this purpose, gal-constitutive strains were employed that express GAL1, GAL7, and GAL10 genes in the absence of the galactose inducer. Genetic crosses were carried out between the rad3-2, dam ${ }^{+}$, and the gal-constitutive $G A L 4^{\mathrm{c}}$ and gal80D strains to obtain strains of the required genotype (Nogi et al. 1977; Mylin et al. 1989). $G A L 4^{c}$ carries a carboxy-terminal deletion in the GAL4 activator protein that abolishes its repressive interaction with $G A L 80$, while gal $80 \Delta$ has the $G A L 80$ repressor gene deleted (Nogi et al. 1977; Mylin et al. 1989). Five rad3-2, $\mathrm{dam}^{+}$segregants from each cross were grown in medium containing glucose or raffinose, and the level of methylation of the Sau3AI site overlapping the XbaI site in the GAL1 coding region was first determined by $E c o$ RI-XbaI double digestion. Subsequently, the $G A L 4^{\mathrm{c}}$ and gal80 $\Delta$ genotype of each segregant was determined by assaying for constitutive expression of GAL10-encoded uridine diphosphoglucose 4-epimerase activity. Results from both crosses showed that only the segregants with a high level of methylation, two from the $G A L 4^{\mathrm{c}}$ cross and all five from the gal80D cross, also exhibited constitutive epimerase expression (Fig. 2; Table 2 ), thus satisfying the prediction. Moreover, the specific epimerase activity of the $\mathrm{dam}^{+}$constitutive segregants was comparable with their respective constitutive parent strains, which lack dam methylase gene, indicating that methylation had no discernable effect on expression of the GAL10 gene (Table 2).

In addition to GAL1 and GAL10, the linked and coregulated $G A L 7$ gene was also found to be more methylated when expressed than when not expressed (data not shown). To address further the question of the generality of the increased methylation of expressed genes in yeast, we analyzed methylation of mating-type loci, the phosphatase genes PHO5 and PHO3, and the cell-type-specific gene STE2. 
A

GAL 1-10 Divergent Promoter

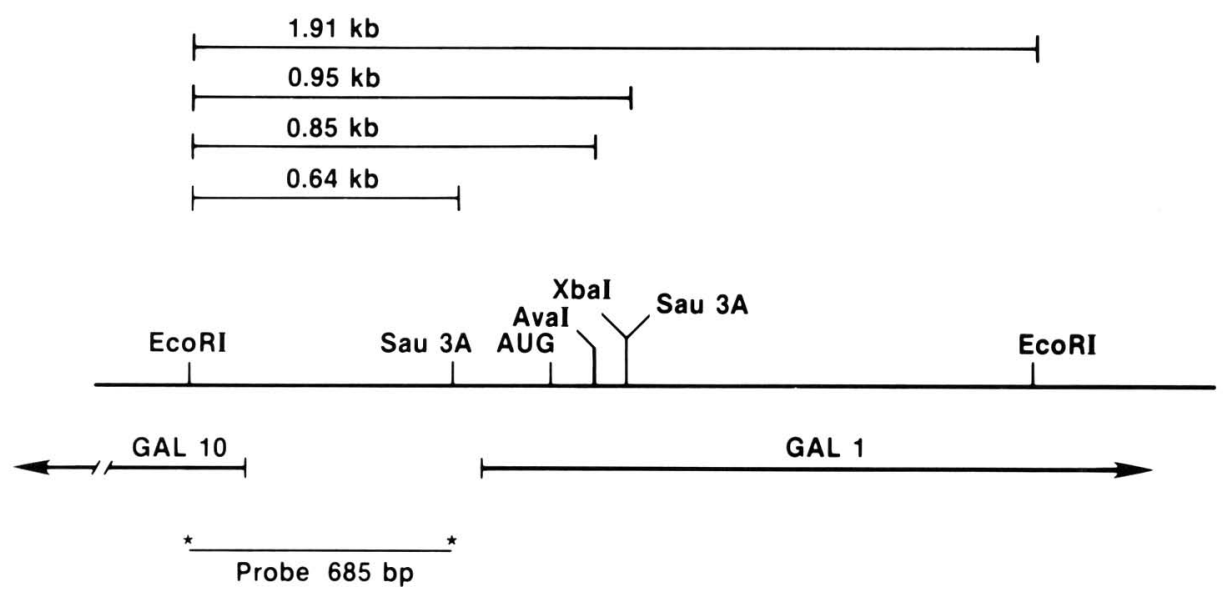

B

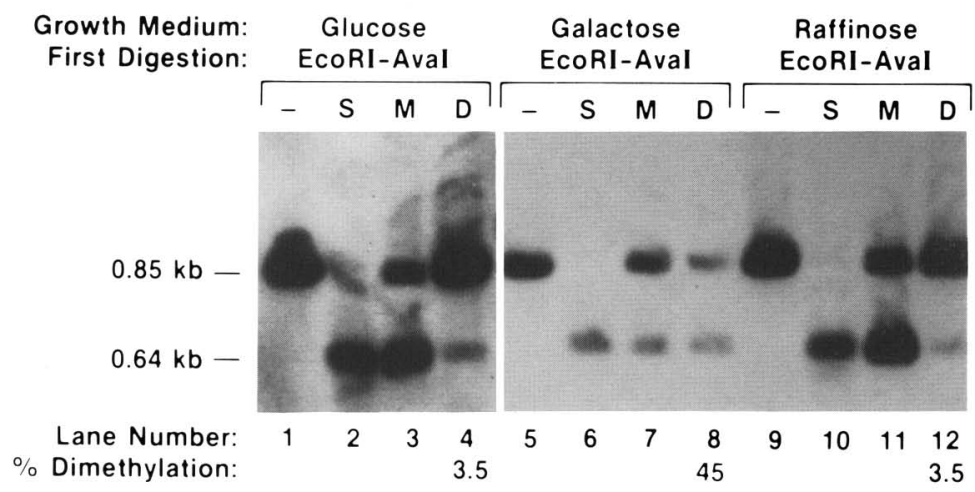

C
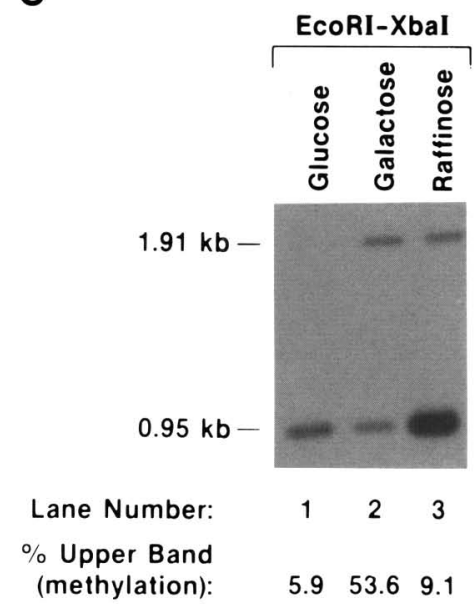

Figure 1. Southern blot analysis of dam methylation of the Sau3AI sites in the GAL1-10 divergent promoter and GAL1 coding region. (A) A partial restriction map of the GAL1-10 divergent promoter. The two Sau3AI sites, whose level of methylation was tested, map within the $1.91-\mathrm{kb}$ EcoRI fragment. The promoter Sau3AI site is located $0.64 \mathrm{~kb}$ from the EcoRI site on its left and is within a region required for transcription of both GAL1 and GAL10. The other Sau3AI site overlaps the XbaI site in the sequence 5' -TCTAGATC-3', located $1.09 \mathrm{~kb}$ to the right of the left EcoRI site. The 685-bp EcoRI-BamHI fragment, isolated from the plasmid pBM150, was used as the probe for indirect end labeling. (B) Methylation of the Sau3AI site in the GAL1-10 promoter. DNA isolated from cells grown in medium containing glucose (lanes 1-4), galactose (lanes 5-8), or raffinose (lanes 9-12) was digested first with EcoRI and $A v a I$, then with Sau3AI (lanes 2, 6, and 10), MboI (lanes 3, 7, and 11), DpnI (lanes 4, 8, and 12), or not subsequently digested (lanes 1, 5, and 9). (C) Methylation of the Sau3AI site in the GAL1 coding region. DNA from cells grown in medium containing glucose (lane 1), galactose (lane 2), or raffinose (lane 3) was digested with EcoRI and XbaI. Strain used was K750 (Table 4). Nearly three times more DNA was loaded in lane 3 as compared to lanes 1 and 2, which can account for greater intensity of the signal in the lower band. Symbols S, M, and $\mathrm{D}$ represent Sau3AI, Mbol, and DpnI, respectively.

\section{dam methylation of mating-type genes}

Strain $\mathrm{K} 750$ was constructed to study methylation of the mating-type loci. This strain contains a temperaturesensitive mutation in the SIR3/MAR2 gene, which is one of the negative regulators of the silent cassettes (Haber and George 1979; Klar et al. 1979; Rine et al. 1979; Rine and Herskowitz 1987). The silent mating-type cassettes $H M L \alpha$ and $H M R$ a are transcriptionally repressed at $25^{\circ} \mathrm{C}$ but active at $35^{\circ} \mathrm{C}$ in the $\operatorname{sir} 3^{\text {ts }}$ mutant. Results of $\mathrm{MboI}$ digests showed that while nearly all of the $4.92-\mathrm{kb}$ HindIII fragment containing HMRa was digested in DNA isolated from the repressed state (Fig. 3A, lane 1), a noticeable amount remained uncut (representing hemi- + dimethylation at all sites in the fragment) in the expressed state (Fig. 3A, lane 5). Other noteworthy changes were at sites located in the structural region of the al and one each in the vicinity of $\mathrm{E}$ and I elements /compare 
Table 1. Quantitation of levels of hemi- and dimethylation of the Sau3AI site in the GAL1-10 promoter

\begin{tabular}{lccc}
\hline $\begin{array}{l}\text { Growth } \\
\text { medium }\end{array}$ & $\begin{array}{l}\text { (A) Hemi + dimethylation (\%) } \\
\text { (MboI lanes) }\end{array}$ & $\begin{array}{l}\text { (B) Dimethylation (\%) } \\
\text { (DpnI lanes) }\end{array}$ & $\begin{array}{l}\text { Hemi-methylation (\%) } \\
(\mathrm{A}) \text { minus (B) }\end{array}$ \\
\hline Glucose & $27.5(72.5)^{\mathrm{a}}$ & 3.5 & 24 \\
Galactose & $72(28)$ & 45 & 27 \\
Raffinose & $28.5(71.5)$ & 3.5 & 25 \\
\hline
\end{tabular}

Data shown in Fig. 1B were quantitated by densitometry.

${ }^{\mathrm{a}}$ The figures in parentheses give the value of unmethylated DNA.

DpnI lanes 2 and 6) that are known to function as cisacting silencer elements (Nasmyth et al. 1980; Abraham et al. 1984; Feldman et al. 1984). It is noteworthy that several sites past the $\mathrm{E}$ region remained largely unaffected by the state of $H M R$ expression. An apparent increase in the DpnI-resistant HindIII fragment in the ex-

A GAL4 ${ }^{c} \times$ wt cross.

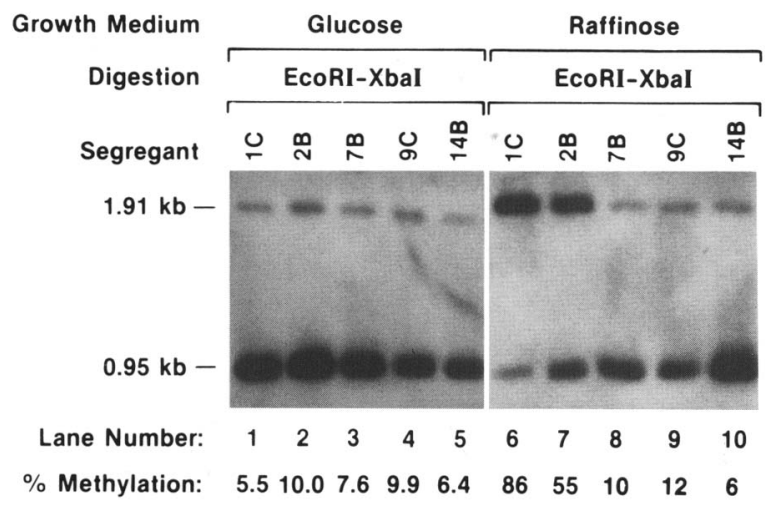

B gal80 $\Delta \times$ wt cross.

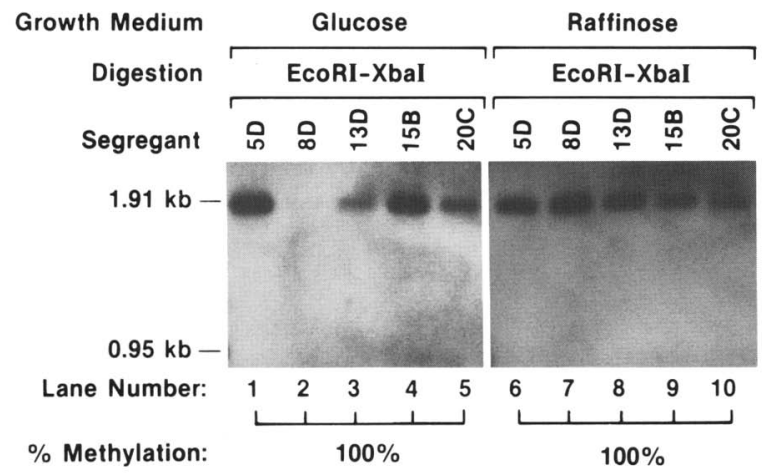

Figure 2. Southern blot analysis of dam methylation of the Sau3AI site in the GAL1 coding region and its relation to galconstitutivity. (A) EcoRI-XbaI-digested DNA from five rad3-2, $\mathrm{dam}^{+}$segregants of a cross between strains SC99 (Gal4 $\left.{ }^{\mathrm{C}}\right)$ and $\mathrm{K} 750\left(G A L^{+}\right)$grown in glucose (lanes 1-5) or raffinose (lanes $6-10)$. (B) EcoRI-XbaI-digested DNA from five rad3-2, dam ${ }^{+}$ segregants of a cross between strains SC285 (Gal80D) and JS1 grown in glucose (lanes 1-5) or raffinose (lanes 6-10). A smaller amount of DNA was loaded in lane 2 and longer exposures did not show any other bands. See Table 4 for genotypes of the strains used. pressed state may result from the slightly higher amount of DNA loaded in lane 6 as compared with that in lane 2.

Similarly, the site c located near the I element of $H M L \alpha$ showed greatly enhanced methylation in the expressed state (compare lanes 2 and 6, Fig. 3B). Site b, located past $\mathrm{c}$ site, remained nearly fully unmethylated under both conditions (lanes 1 and 5). Our data provide no information on the level of methylation of site a because it is inherently resistant to digestion even with Sau3AI.

The dam methylase gene is derived from $E$. coli, which grows better at higher temperature $\left(37^{\circ} \mathrm{C}\right)$. Therefore, the methylase activity may work inherently better at $35^{\circ} \mathrm{C}$ as compared with that at $25^{\circ} \mathrm{C}$. However, we found that only specific sites, not all the sites, exhibit increased dimethylation in $H M L \alpha$ and $H M R$ a ruling out the possibility that growth at higher temperature leads to generally greater methylation in the experiment presented above. Second, the mating test is known to be a very sensitive assay of silent gene expression. Using this test, sir ${ }^{\text {ts }}$ was found to be a tight mutation, as the mutant mates well at the permissive temperature (indicating full repression of $H M$ loci), but is fully sterile at the restrictive temperature. Thus, we presume that the level of methylation reflects the difference in the state of expression. In addition, methylation of sites in another constitutively expressed mating-type cassette MATa was assayed as an internal control. Results (Fig. $3 \mathrm{C}$ ) indicated that the MATa locus exhibited a similar high level (about $90 \%$ ) of methylation of the Sau3AI site in the al region at both temperatures, as evidenced by a lack of digestion of the $3.5-\mathrm{kb}$ fragment to $3.0 \mathrm{~kb}$ by $\mathrm{MboI}$. In addition, the site lying outside the $Z$ region remained largely unmethylated at both temperatures, as indicated by complete digestion of the 4.2-kb HindIII fragment by MboI.

Strain K750 exhibited complete sterility because it failed to mate with an $\alpha$ tester strain at $35^{\circ} \mathrm{C}$. We presume that the normally silent cassettes are indeed turned on at $35^{\circ} \mathrm{C}$ and, seemingly, methylation does not affect their expression.

The indirect end-labeling approach can only allow quantitation of methylation of the site immediately flanking the probe and the proportion of molecules that are methylated (hemi- or full) at all sites (Mbol-resistant) or are not fully methylated at all sites (DpnI-resistant). Because of the presence of multiple sites in $H M R \mathbf{a}$, the level of methylation of individual sites near $\mathrm{E}$ and I cannot be quantitated (Fig. 3A). In addition, the apparently small differences observed may be explained by a tem- 
Table 2. Specific activities of epimerase in the segregants from the crosses involving Gal-constitutive strains

\begin{tabular}{|c|c|c|c|c|}
\hline & \multirow[b]{2}{*}{ Segregant } & \multicolumn{3}{|c|}{$\begin{array}{c}\text { Epimerase activity } \\
(\text { expressed in } \mathrm{nmole} / \mathrm{mg} \cdot \mathrm{hr})^{\mathrm{a}}\end{array}$} \\
\hline & & glucose & raffinose & galactose \\
\hline Cross & $1 \mathrm{C}$ & $<5$ & 188.2 & $\mathrm{ND}^{\mathrm{b}}$ \\
\hline \multirow[t]{4}{*}{$G A L^{+}(\mathrm{K} 750) \times G A L 4^{\mathrm{c}}(\mathrm{Sc} 99)$} & $2 B$ & $<5$ & 102.9 & ND \\
\hline & $7 \mathrm{~B}$ & $<5$ & $<5$ & ND \\
\hline & $9 \mathrm{C}$ & $<5$ & $<5$ & ND \\
\hline & $14 \mathrm{~B}$ & $<5$ & $<5$ & ND \\
\hline \multirow[t]{5}{*}{$J S 1 \times \operatorname{gal} 80 \Delta(\mathrm{Sc} 285)$} & $5 \mathrm{D}$ & 302.9 & 417.3 & ND \\
\hline & $8 \mathrm{D}$ & 171.6 & 218.3 & ND \\
\hline & $13 \mathrm{D}$ & 410.4 & 745.4 & ND \\
\hline & $15 B$ & 113.7 & 250 & ND \\
\hline & $20 \mathrm{C}$ & 133.5 & 1075 & ND \\
\hline \multicolumn{5}{|l|}{ Control strains } \\
\hline Sc99 & & 60.7 & 74.9 & ND \\
\hline Sc285 & & 222 & 168.7 & ND \\
\hline K750 & & $<5$ & $<5$ & 49.6 \\
\hline
\end{tabular}

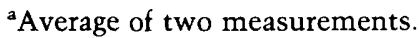

b(ND) Not determined.

perature effect in sit $3^{\text {ts }}$ strains. To address both of these points, we investigated individual methylation-sensitive sites, namely the $A l w I$ site in the $\mathrm{E}$ region and the $B c l \mathrm{I}$ site in the I region in a mar2s strain. The important result is that both sites were insensitive to digestion in the expressed (mar2s) state, indicating a high level (nearly $100 \%$ ) of methylation. Under the repressed state, about $15 \%$ of DNA was unmethylated at the Bcll site and $40 \%$ at the AlwI site.

\section{PHO5 and PHO3 genes}

PHO5 is repressed at high concentrations of $\mathrm{P}_{\mathrm{i}}$ (inorganic phosphate) while the adjoining gene $\mathrm{PHO} 3$ is expressed constitutively (Meyhack et al. 1982). The striking result was that sites located in the promoter $(0.34 \mathrm{~kb})$ and coding region $(1.65 \mathrm{~kb})$ of $P H O 5$ were only slightly methylated $(-5 \%$ digestion by $D p n I)$ under the repressed state (Fig. 4, lane 2). They became nearly completely dimethylated $(\sim 90 \%)$ under the expressed state (lane 6 ). [Although the band intensities of lane 6 are weaker than that in lane 5, the amount of DNA loaded (as judged by ethidium staining/ was very similar. Moreover, the fact that the $D p n I$ digestion pattern appeared very similar to the Sau3AI pattern (lane 4) and that longer exposures did not indicate slower migrating bands in lane 6 (data not shown) indicated that the sites in PHO5 gene were indeed nearly completely methylated under expressed state. Furthermore, the critical aspect of the data comprises comparison of intensities of different fragments displayed in the same lane with each other.] $\mathrm{PHO} 3$ also exhibited subtle changes that were less pronounced than PHO5 gene. Two sites within the coding region of $\mathrm{PHO} 3$ appeared to be less cut with $\mathrm{MboI}$, while the other two sites in the $3^{\prime}$-flanking sequences are slightly more digested in low $\mathrm{P}_{\mathrm{i}}$ medium.
In vivo accessibility of yeast chromatin to $\mathrm{B}$. subtilis phage SPR methylase

We used strains containing the plasmid-borne B. subtilis phage SPR methylase gene (Kiss and Baldauf 1983) expressed under the control of the GAL1 promoter (Feher et al. 1988). This methylase modifies both the $\mathrm{C}$ residues of the HpaIl site, CCGG, and the internal C residue in the sequences GGCC and CCA/TGG (Kiss and Baldauf 1983). Methylation of the internal C in CCGG site confers resistance to digestion with HpaII. When either or both $\mathrm{C}$ residues are methylated, $M s p I$ cannot cleave the site (Keshet and Cedar 1983). Because the protocol required expression of the methylase gene by growing cells in galactose, methylation of the GAL1-10 system could not be analyzed. Instead, we subjected the cell-type-specific genes STE2 and STE3 to this analysis (Sprague et al. 1983; Nakayama et al. 1985). A lack of digestion of the 0.92 -kb fragment at the sequence $5^{\prime}$-ACCGGC- $3^{\prime}$ by MspI and HpaII indicated complete methylation of both the $\mathrm{C}$ residues of the site located in the promoter in a cells that express the STE2 gene (Fig. 5). However, in $\alpha$ cells not expressing the STE2 gene, a significant fraction of the $0.92-\mathrm{kb}$ fragment was digested by both $\mathrm{MspI}$ and HpaII, generating the $0.8-\mathrm{kb}$ fragment, reflecting only a partial methylation of the same site. It is also clear that both Cs were methylated to different extents in $\alpha$ cells, as indicated by the difference in cleavage by $M s p I$ and HpaII.

Similarly, an analysis of the STE3 gene, which is not expressed in a cells (Sprague et al. 1983; Nakayama et al. 1985 ), showed a nearly complete digestion of the 1.24-kb fragment by MspI (Fig. 6, lane 2). This result indicated a very low level of methylation $(2-4 \%)$ in the promoter region. In contrast, about $15 \%$ of the fragment remained undigested and was, therefore, methylated in $\alpha$ cells that express the gene (Fig. 6, lane 5). The same site was completely digested with HpaII (Fig. 6, lanes 3 and 6) under 
A

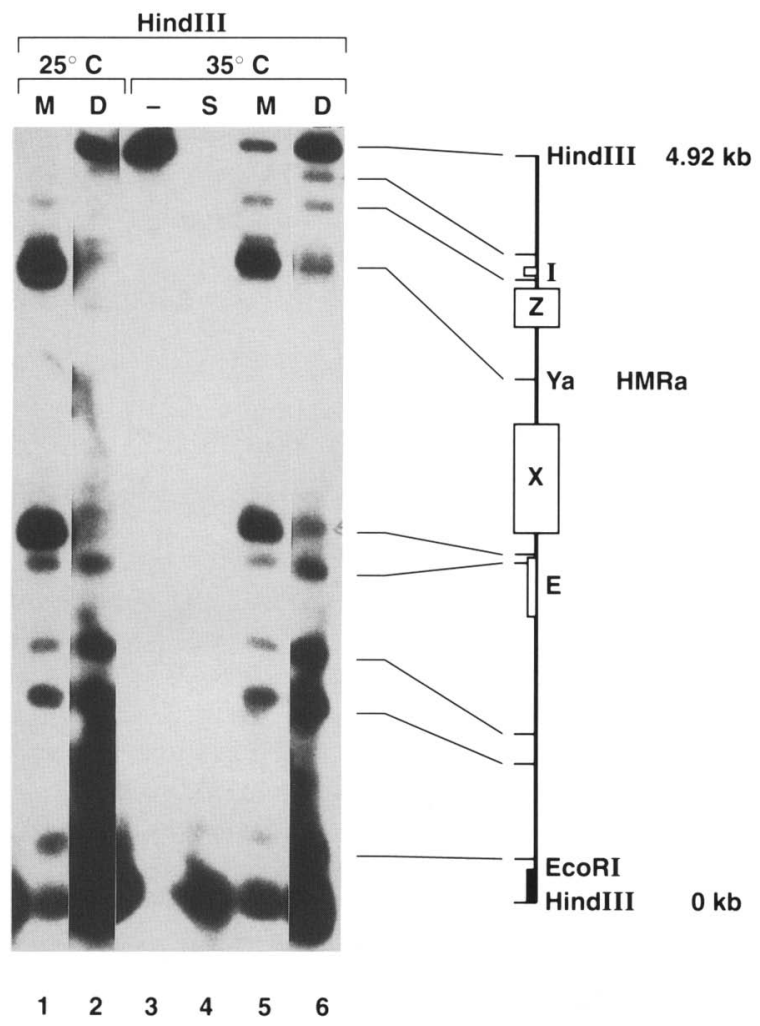

B

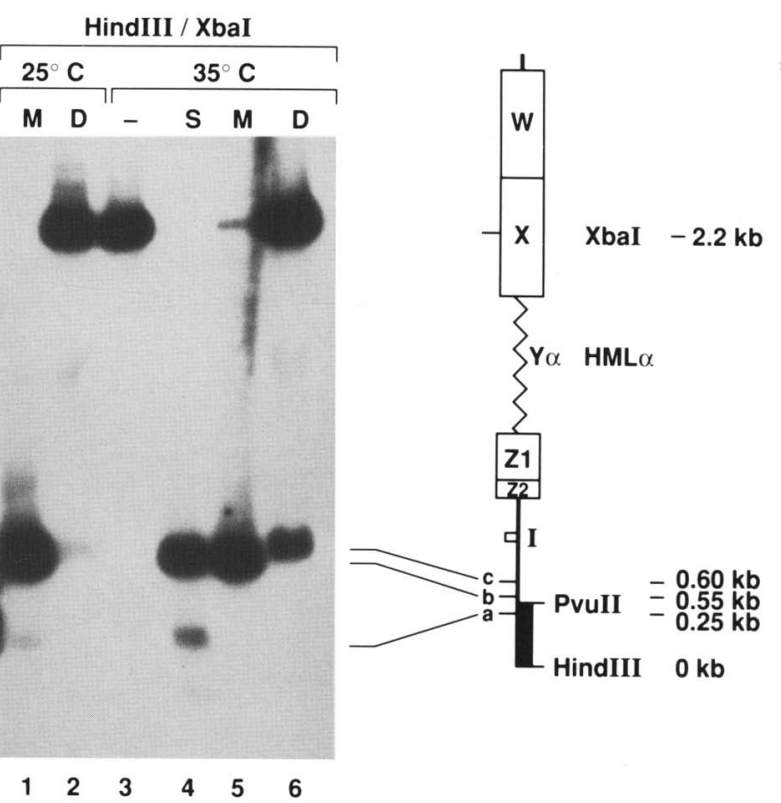

C

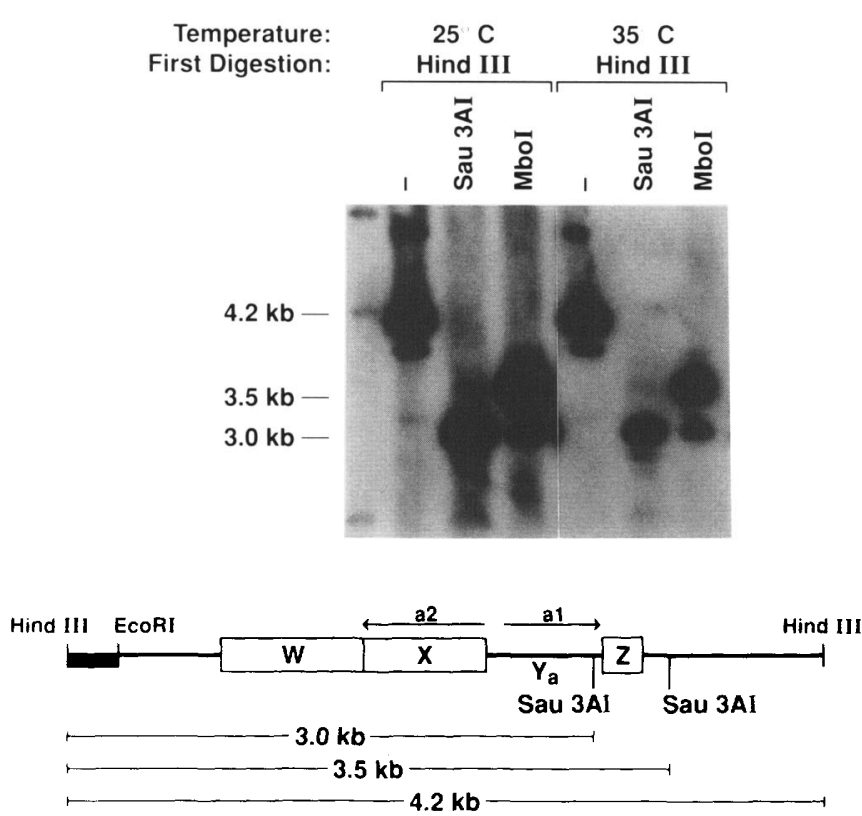

D

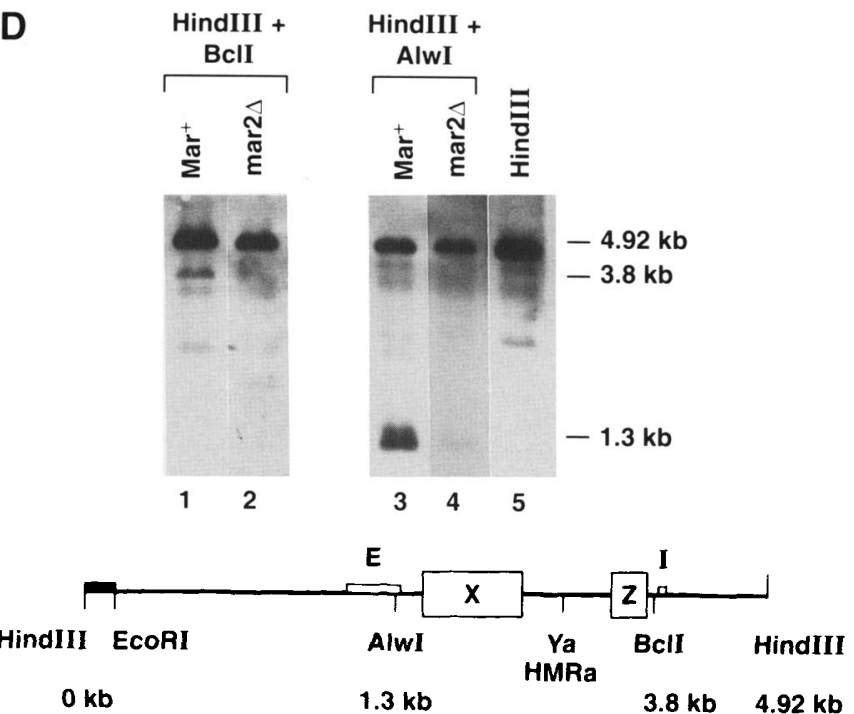

HindIII +

AlwI

Figure 3. Southern blot analysis of dam methylation of mating-type loci in a sir $3^{\text {ts }}$ strain $(\mathrm{K} 750 ; A, B$, and $C)$ and the mar2 $\mathrm{strain}$ (D). (A) HMRa. DNA from cells grown at indicated temperatures was digested with HindIII alone (lane 3), HindIII plus Sau3AI (lane 4), HindIII plus $M b o I$ (lanes 1 and 5) or HindIII plus DpnI (lanes 2 and 6). $(B) H M L \alpha$. DNA was digested with HindIII and XbaI (lane 3) followed by digestion with Sau3AI (lane 4), MboI (lanes 1 and 5), or DpnI (lanes 2 and 6). (C) MATa. DNA was digested with HindIII alone, HindIII plus Sau3AI, HindIII plus $\mathrm{MboI}$ as indicated. (D) HMRa. DNA from Mar ${ }^{+}$(lanes 1, 3, and 5) and mar2 (lanes 2 and 4) strains was digested with HindIII alone (lane 5), HindIII plus Bcll (lanes 1 and 2) or HindIII plus AlwI (lanes 3 and 4). The probes used for indirect end labeling were the HMRa (centromere)-proximal HindIII-EcoRI fragment for $A$ and $D$, the $H M L \alpha$-proximal $H i n d I I I-$ $P$ vuII fragment for $B$, and the MATa-proximal HindIII-EcoRI fragment for $C .25^{\circ} \mathrm{C}$ and $35^{\circ} \mathrm{C}$ indicate the growth temperature of the culture. 

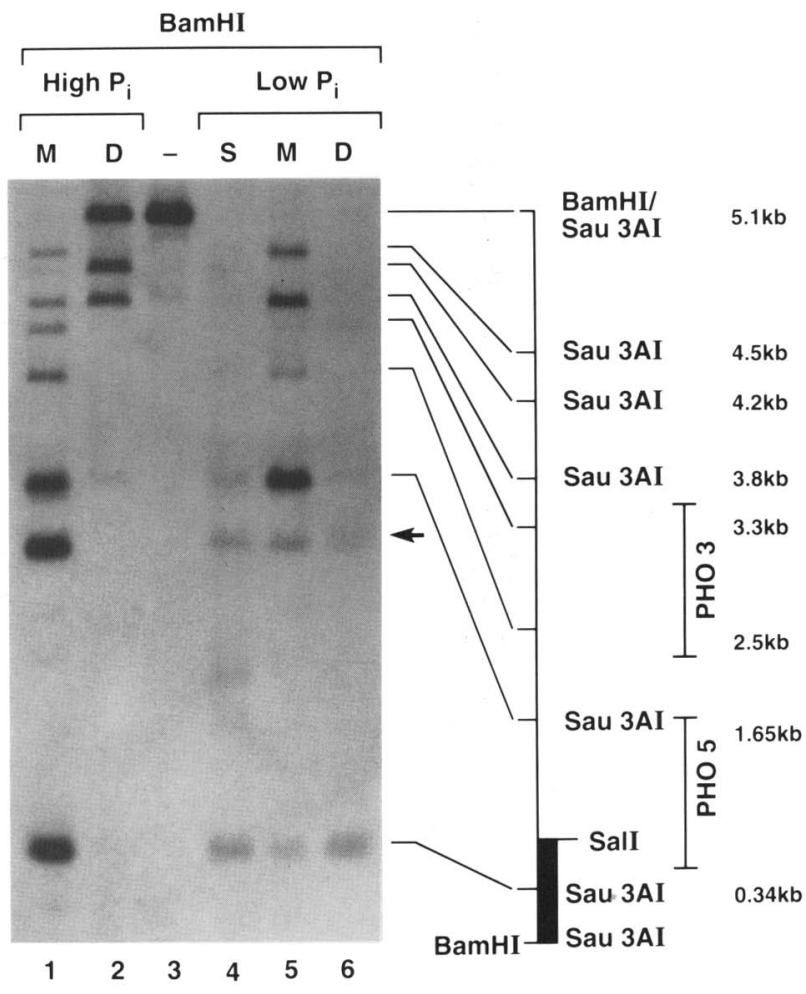

Figure 4. Southern blot analysis of dam methylation of the linked genes $P H O 5$ and $P H O 3$. DNA isolated from cells grown in medium containing high (lanes 1 and 2) or low (lanes 3-6) levels of $\mathrm{P}_{\mathrm{i}}$ was digested with $\mathrm{BamHI}$ followed by $\mathrm{MboI}$ (lanes 1 and 5), Sau3AI (lane 4), or DpnI (lanes 2 and 6). The BamHI-Sall fragment was used as the probe for indirect end labeling. The arrow indicates the DNA fragment resulting from digestion at both Sau3AI sites contained within the BamHI-SalI fragment used as the probe, and the Sau3AI located in the PHO5 coding region. In addition, the strain used also contains another Sau3AI site located close but distal to the $1.65-\mathrm{kb}$ site. The site located at $0.34 \mathrm{~kb}$ is situated in the promoter and that at $1.65 \mathrm{~kb}$ is situated in the $3^{\prime}$ end of the PHO 5 coding region.

both conditions, indicating a lack of methylation of the $3^{\prime} \mathrm{C}$ residue.

\section{Discussion}

\section{Correlation between the level of methylation and gene expression}

The most significant finding is that all the yeast genes we tested exhibited increased methylation in the expressed state (Tables 1 and 3 ), and sites within and outside of the coding sequences were affected. Our interpretation of the finding is that increased methylation reflects increased accessibility of the active chromatin to methylases in vivo. The most extensive study was carried out with the $G A L$ genes that showed a greater than 10-fold increased level of dimethylation in the expressed state. However, the level of hemimethylation of the promoter site was not altered (Table 1). The basis for the high, unchanged level of hemimethylation of the GAL1-
10 promoter site is not known. It may reflect a consequence of replication, a time during which the chromatin template may become transiently unfolded and gets hemimethylated randomly on one or the other strand at a particular site, but not enough of a time window exists for dimethylation. This point needs to be resolved further.

A comment should be made regarding the differences in the level of methylation of $G A L$ genes in wild-type cells grown in galactose-containing medium, as compared to those of constitutive gal80 $\mathrm{A}$ and $G A L 4^{\mathrm{c}}$ cells grown in glucose or raffinose medium. A lack of glucose repression (Table 2) and nearly complete methylation of the site in GAL1 coding region (as well as the promoter region; data not shown) was observed in gal80 $\Delta$ strains. $G A L 4^{c}$ strains are still repressible by glucose; the constitutivity ensues with growth in raffinose medium $(\mathrm{Ta}$ ble 2). Consistent with this, Lohr and Hopper (1985) observed that gal80 strains exhibit greater GAL1 transcription as well as greater DNase I digestion as compared to $G A L 4^{\mathrm{c}}$ strains when grown in glucose-containing medium. Thus, in the $G A L$ system, it appears that increased expression of the gene was correlated with enhanced levels of methylation.

Likewise, the highly regulated $\mathrm{PHO} 5$ gene was only slightly $(5 \%)$ methylated at the promoter site in the repressed state but was highly methylated $(90 \%)$ upon activation (see Table 3). The adjoining $\mathrm{PHO} 3$ gene also showed detectable but less pronounced changes. Although the $\mathrm{PHO} 3$ gene is considered to be expressed constitutively (Meyhack et al. 1982), the observed subtle changes in methylation pattern in low $\mathrm{P}_{\mathrm{i}}$ medium may reflect changes in the level of expression. Similarly, sites located near the important regulatory $\mathrm{E}$ and I regions of

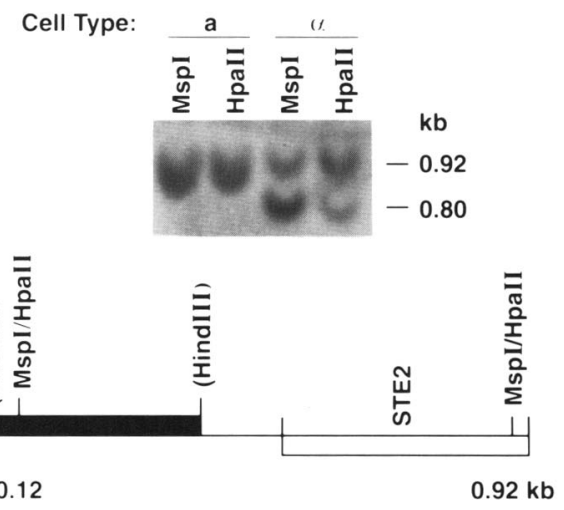

Figure 5. Southern blot analysis of $\mathrm{CpG}$ methylation of the $S T E 2$ gene. DNA prepared from isogenic strains JSa (SPR) and IS $\alpha$ (SPR) expressing a galactose-inducible $B$. subtilis phage SPR methylase was digested with $M s p I$ or $H p a I I$ as indicated. The line drawing shows the restriction map of STE2; HindIII sites in parentheses are based on the work of Nakayama et al. (1985), but our strain lacks these sites. The fragment represented by a filled in box was used as the probe for indirect end labeling. The open box indicates the open reading frame of the gene. The site being studied is located upstream of the $5^{\prime}$ end of the coding region. 


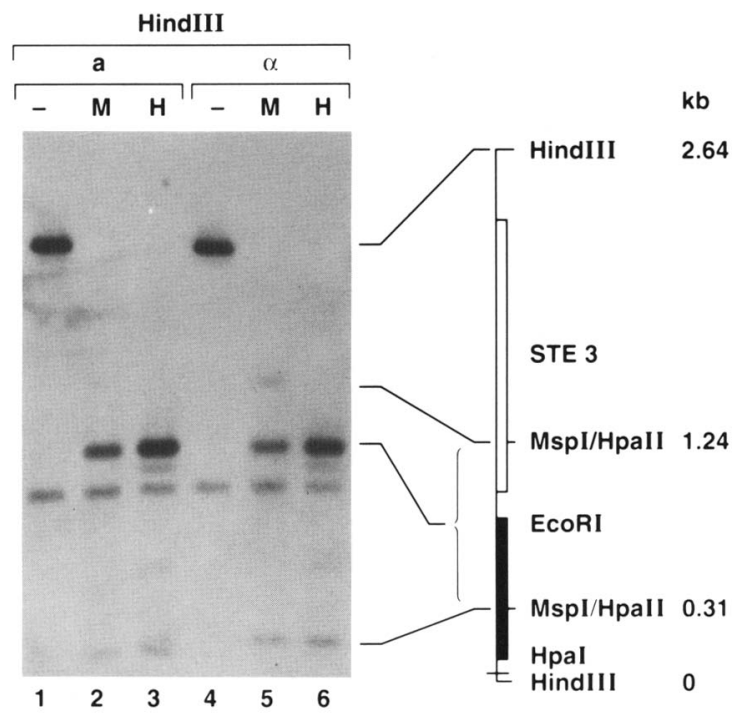

Figure 6. Southern blot analysis of CpG-methylation of the STE3 gene. DNA isolated from isogenic strains JSa (SPR) (lanes 1-3) and JS $\alpha$ (SPR) (lanes 4-6) expressing the SPR methylase was digested with HindIII, followed by MspI (lanes 2 and 5) or HpaII (lanes 3 and 6). Lanes 1 and 4 display the control HindIII digests. The HpaI-EcoRI fragment of the STE3 gene was used as the probe for indirect end labeling. The origin of the common band of $\sim 700 \mathrm{bp}$ seen in all the lanes is not known. The $1.24-\mathrm{kb}$ site is located within the coding region, while that at $0.31 \mathrm{~kb}$ is situated upstream of the $5^{\prime}$ end of the gene.

$H M L$ and $H M R$ loci exhibited increased methylation when these normally cryptic loci were expressed in $\operatorname{sir} 3^{\text {ts }}$ and mar2s strains.

An interesting finding of this study was that all of the sites showing altered levels of methylation in $H M L \alpha$ and $H M R \mathbf{a}$, as also in case of $P H O 3$, did not lie in a transcriptional unit or near the promoter. In fact, some lie in the $3^{\prime}$ end of transcriptional units originating from an internal divergent promoter. These findings suggest that activation of both the silent cassettes might involve an unfolding or opening-up of a whole domain spanning the accessible sites, which, in turn, might increase their accessibility to the transcriptional apparatus. These results may be viewed in light of a recent report showing that the $\mathrm{E}$ and $\mathrm{I}$ regions can interact with one another and with a site within the $\mathrm{Y}$ region via the protein RAP1, thus forming the hypothetical repression loop (Hofmann et al. 1989). Activation of the cassettes might involve breaking these interactions, resulting in unfolding and greater accessibility of the region.

Another point concerns the extent of correlation between the level of methylation and the level of transcription of a particular gene. The genes we chose to study reflect a broad spectrum of the level of transcription. In general, our results are consistent with a direct correlation, given that GAL and PHO5 genes are heavily transcribed and STE2 and HM loci are transcribed inefficiently. Clearly, however, the correlation is not absolute. For example, a site in the weakly expressed MATa was also highly methylated. A more likely explanation is that chromatin context effect may modulate the extent of methylation not only of each gene but also of each site. Another important question that is beyond the scope of this study is whether the act of transcription per se, as opposed to changed chromatin structure, or both features promote methylase accessibility. We note, however, that many sites whose methylation level was increased are outside of the transcription unit.

The limited amount of data for cytosine methylation of STE2 and STE3 genes also showed increased methylation of active genes. The different levels of methylation of adjoining $\mathrm{C}$ residues of the HpaII site in the STE2 promoter in $\alpha$ cells may reflect their differential accessibility to methylation in chromatin, or differential substrate specificity of the enzyme. On the other hand, a significant level of methylation of the external, but not the inner, $\mathrm{C}$ residue of the HpaII site in the STE3 promoter may occur because of the protection of the inner $\mathrm{C}$ residue by a bound protein in chromatin.

\section{Methylation as a probe for accessible regions of chromatin}

Our results show that in vivo methylation by a foreign methylase, especially dam methylase, can serve as a powerful probe for studying the in vivo accessibility of yeast genes during transcription, and possibly during replication and recombination. Since higher eukaryotes do not contain high levels of $\mathrm{N}^{6}$-methyladenine, this approach can be of potential use to study their in vivo chromatin structure. This novel in vivo experimental approach contrasts and complements the currently used semi-in vivo nick-translation (Levitt et al. 1979) and in vitro DNase I (Weintraub and Groudine 1976) approaches for studying chromatin structure. Our approach is simpler, and, also because it is in vivo in nature, is not subject to experimental artifacts.

We realize that our system is limited to the analysis of endogenously present GATC sites in the genome. Such sites may be incorporated in the region of interest by in vitro mutagenesis. On the other hand, presence of multiple GATC sites in a restriction fragment of interest makes the analysis difficult. One way to focus on a particular site is to use one of many "6-base-cutter" endonuclease activities available whose recognition sequence overlaps the GATC site and whose activity is sensitive to methylation. Another potential application of the technique is to exploit the acquired DpnI sensitivity of active genes to isolate differentially expressed loci from different cell types.

\section{Correlation with previous studies on yeast chromatin}

Several studies have been reported on the chromatin structure of different genes of yeast, especially for $\mathrm{PHO5}$ PHO3 and mating-type loci. Presence of an inducer independent DNase I hypersensitive site that is located 370 bp upstream of the PHO5 gene has been demonstrated by Fascher et al. (1990). This site contains a major UAS element flanked by specifically positioned nucleo- 
Table 3. Quantitation of levels of dam and cytosine methylation at different loci

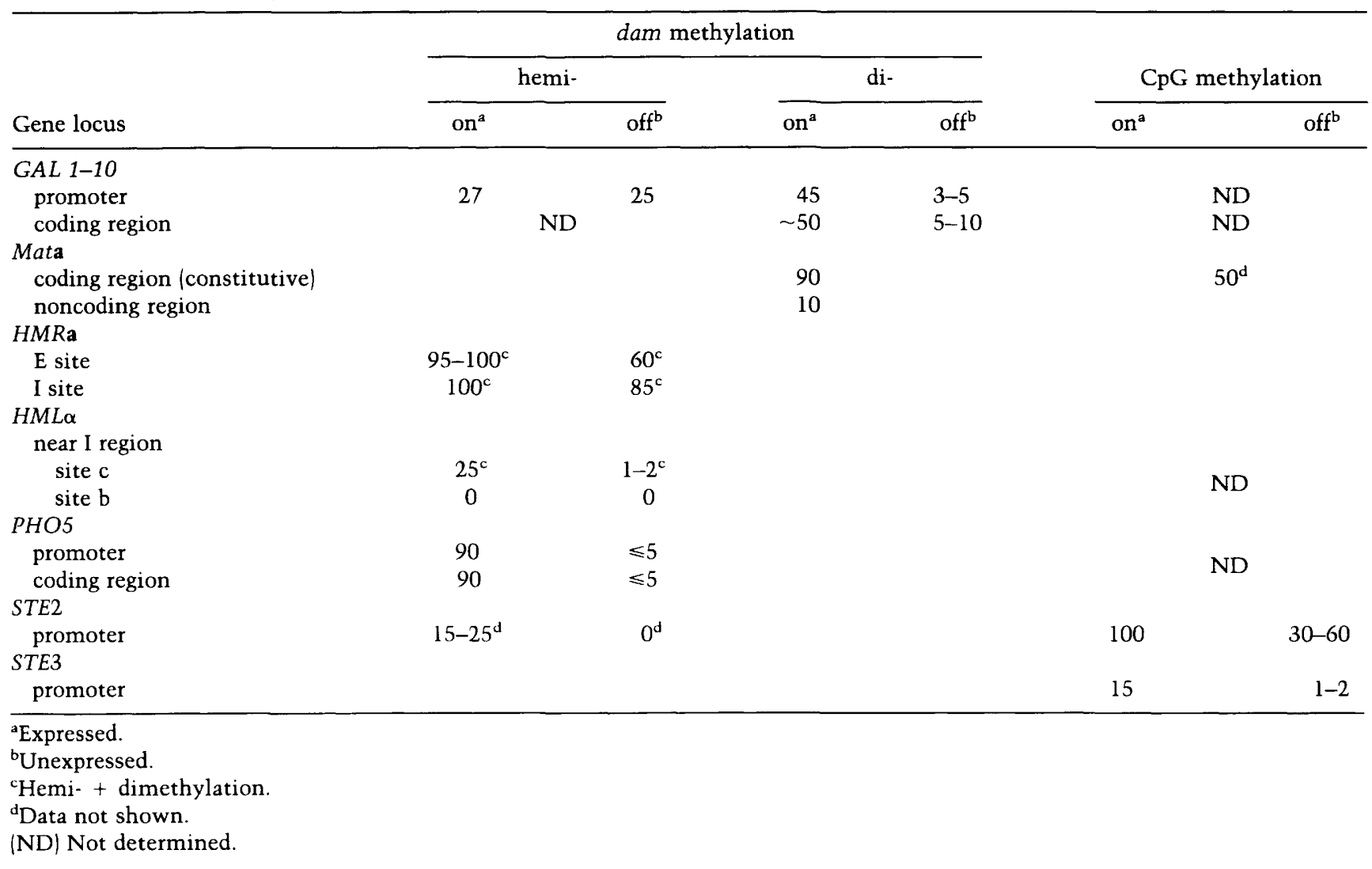

somes. Induction of the gene under low $\mathrm{P}_{\mathrm{i}}$ condition leads to removal of two nucleosomes upstream and two nucleosomes downstream of this site (Fascher et al. 1990). Accordingly, the Sau3AI site in that region also became accessible to methylation. We also found increased methylation of a site in the PHO5 coding region where no DNase I hypersensitive site has been reported. In fact, this region is known to be covered with nucleosomes (Fascher et al. 1990). Thus, increased methylation of that site implies that DNA methylation is occurring in chromatin rather than on naked DNA.

In an interesting analysis of chromatin organization of the mating-type loci, Nasmyth (1982) showed that MAR/ $S I R$ genes are responsible for the loss of several DNase I sensitive sites located between $\mathrm{E}$ and I regions at the $H M$ loci. These in vitro results are in accord with our in vivo results showing increased level of methylation of sites delimited by $\mathrm{E}$ and I regions. Altered chromatin structure of the $H M$ loci in the expressed state was also indicated by the accessibility of these loci to $\mathrm{HO}$-encoded endonuclease (Klar et al. 1981) and DNA repair (Terleth et al. 1989).

Role of DNA methylation in gene expression in higher eukaryotes

Most of our studies involved adenine methylation. The effect of adenine methylation on gene regulation in higher eukaryotes is not known; however, CpG methylation is generally inversely correlated with gene expression in higher eukaryotes. Thus, our this study has no direct bearing on the question of the role of DNA methylation in gene expression in higher eukaryotes. It is now widely accepted that $\mathrm{CpG}$ methylation plays a role in maintenance of the inactive state of chromatin (for review, see Cedar 1988). The most direct link between site-specific demethylation and gene activation has been provided by Saluz et al. (1986) and Wilks et al. (1982) for the vitellogenin promoter. However, the issue of cause or consequence of methylation on gene expression is not clearly understood. It does remain an active area of research.

In our system of yeast strains expressing foreign DNA methylases, methylation reflects the state of expression of yeast genes and is, therefore, a consequence of gene expression. A potential application of our study to higher eukaryotes may be in developing an in vivo dam methylation system for monitoring early changes in chromatin accessibility during changes in gene regulation.

\section{Materials and methods}

Strains and plasmids

The strains used in this study and their genotypes are listed in Table 4. The strains expressing dam methylase gene were obtained by crossing the original strains (provided by Bob Malone) 
Table 4. Strains used in this study

\begin{tabular}{|c|c|c|}
\hline Strain & Genotype & Source \\
\hline K750 & MATa $\operatorname{sir} 3^{\mathrm{ts}}, \operatorname{cry}_{1}{ }^{\mathrm{r}}$, his 4 or -7, ade2, leu2, $\operatorname{rad} 3-2, \mathrm{dam}^{+}, \mathrm{GAL}^{+}$ & this work \\
\hline JS1 & $M A T \mathbf{a}, \operatorname{sir} 3^{\text {ts }}, \operatorname{cry}_{1}{ }^{\mathrm{r}}$, ade2, leu2, $\operatorname{rad} 3-2, \mathrm{dam}^{+}, \mathrm{gal}^{-}$ & this work \\
\hline SC99 & $M A T \alpha, G A L 4^{\mathrm{c}}$, his $^{-}, \mathrm{GAL}^{+}, a d e^{-}$ & J. Hopper \\
\hline SC285 & 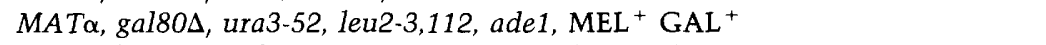 & J. Hopper \\
\hline $9 \mathrm{Ca}$ & MATa, his4 or -7, leu2, cry $^{\mathrm{r}}, \operatorname{rad} 3-2$, dam $^{+}, \mathrm{GAL}^{+}$ & this work \\
\hline $9 \mathrm{C} \alpha$ & MAT $\alpha$, his 4 or -7, leu2, cry $^{1}, \operatorname{rad} 3-2$, dam $^{+}, \mathrm{GAL}^{+}$ & this work \\
\hline $\mathrm{JSa}(\mathrm{SPR})$ & MATa, his3- $\Delta 200$, leu2- $\Delta 1, \operatorname{trp} 1-\Delta 1$, tyr $7-1$, ura3-52, $\mathrm{GAL}^{+}(\mathrm{GALl}-\mathrm{SPR})$ & this work \\
\hline $\mathrm{JS} \alpha(\mathrm{SPR})$ & MAT $\alpha: U R A 3$, his $3-\Delta 200$, leu2- $\Delta 1, \operatorname{trp} 1-\Delta 1, \operatorname{tyr} 7-1$, ura3-52, GAL ${ }^{+}$(GAL1-SPR) & this work \\
\hline
\end{tabular}

containing the chromosomally integrated dam methylase gene with other suitable strains. The methylase gene in these strains is expressed constitutively under the control of its own promoter.

\section{Growth conditions and genetic analysis}

Standard procedures for growth and genetic analysis of yeast were followed according to Sherman et al. (1983). Cells were grown in YEP medium containing glucose $(2 \%)$, galactose $(2 \%)$, or raffinose $(5 \%)$. To study methylation of mating-type loci, the strain $\mathrm{K} 750$ was grown to mid-log phase in YEPD medium at the permissive $\left(25^{\circ} \mathrm{C}\right)$ or restrictive $\left(35^{\circ} \mathrm{C}\right)$ temperatures.

For studying methylation of linked genes $\mathrm{PHO} 5-\mathrm{PHO} 3$, the strain $\mathrm{K} 750$ was grown in low and high $\mathrm{P}_{\mathrm{i}}$ media to mid-to-late log phase. The low $\mathrm{P}_{\mathrm{i}}$ medium was prepared according to Rubin (1974).

For studying cytosine methylation of yeast genes STE2 and STE3, isogenic JSa (SPR) and JS $\alpha$ (SPR), strains expressing the $B$. subtilis SPR phage cytosine methylase under the control of GAL1 promoter (Feher et al. 1988) were grown in YNB-Leu + raffinose. After growing to mid-log phase, the methylase was induced by adding galactose to a final concentration of $2 \%$ and further growth for 8-12 hr.

DNA preparation, gel electrophoresis, and Southern hybridization

The genomic DNA was prepared from yeast cells according to Abraham et al. (1984). After an overnight digestion with 15- to 20-fold excess of the appropriate enzyme, to ensure complete digestion 4-5 additional units of the enzyme were added and incubation continued for additional $4-6$ hours. As a control for the completion of digestion $0.5 \mu \mathrm{g}$ of the 643-bp Aval-PvuII fragment of pBR322 DNA (isolated from dam $^{-}$and $\mathrm{dam}^{+}$ strains), which contains two Sau3AI sites, was added to the $M b o I$ and DpnI reactions. The digests were resolved by electrophoresis in $1-1.2 \%$ agarose gel in $1 \times$ TAE buffer. Complete digestion was indicated by the generation of 401 - and 242-bp bands and the loss of the pBR322 643-bp band (data not shown). After blotting to Nytran membrane according to Southern (1975), overnight hybridization was done, followed by highstringency washes and autoradiography at $-70^{\circ} \mathrm{C}$ with an intensifying screen. Band intensities were quantitated by densitometry. Each set of experiments was repeated three times producing reproducible results. Percent dimethylation was estimated by calculating the intensity of the smaller band resulting from $D p n I$ digestion in Figures 1 and 2 as a percentage of the sum of both the bands.
Scoring the $\mathrm{dam}^{+}$segregants

The $\mathrm{dam}^{+}$segregants were identified as their DNA gained sensitivity to digestion by DpnI. The genomic DNA from damsegregants remained undigested by $D p n I$. The digests were electrophoresed in agarose gels and the DNA was visualized by staining with ethidium bromide.

\section{Enzyme activities and protein estimation}

The epimerase activity was measured by the two-step protocol of Kalckar et al. (1959). The protein estimation was done by Bradford Assay and the specific epimerase activity was expressed as nmole/mg.hr.

\section{Acknowledgments}

This work would not have been possible without the original studies and some of the strains provided by R. Malone and S. Hattman. We are also thankful to J. Hopper for strains containing GAL4 and gal80D mutations; S. Austin, D. Court, B. Arcangioli, S. Hughes, P. Johnson, P. Sutrave, P. Rogan, and A. Arthur for helpful suggestions and critical review of the manuscript; R. Frederickson for preparation of the figures; and P. Hall and S. Lucas for expert secretarial assistance.

This research was sponsored by the National Cancer Institute, DHHS, under contract No. N01-CO-74101 with ABL. The contents of this publication do not necessarily reflect the views or policies of the Department of Health and Human Services, nor does mention of trade names, commercial products, or organizations imply endorsement by the U.S. Government.

By acceptance of this article, the publisher or recipient acknowledges the right of the U.S. Government and its agents and contractors to retain a nonexclusive royalty-free license in and to any copyright covering the article.

The publication costs of this article were defrayed in part by payment of page charges. This article must therefore be hereby marked "advertisement" in accordance with 18 USC section 1734 solely to indicate this fact.

\section{References}

Abraham, J., K.A. Nasmyth, J.N. Strathern, A.J.S. Klar, and J.B. Hicks. 1984. Regulation of mating-type information in yeast. Negative control requiring sequences both $5^{\prime}$ and $3^{\prime}$ to the regulated region. I. Mol. Biol. 176: 307-331.

Cedar, H. 1988. DNA methylation and gene activity. Cell 53: 34.

Fascher, K.-D., J. Schmitz, and W. Horz. 1990. Role of transactivating proteins in the generation of active chromatin at the PHO5 promoter in S. cerevisiae. EMBO I. 9: 2523-2528.

Feher, Z., S.L. Schlagman, Z. Miner, and S. Hattman. 1988. In 
vivo methylation of yeast DNA by prokaryotic DNA methyltransferases. Gene 74: 193-195.

Feldman, J.B., J.B. Hicks, and J.R. Broach. 1984. Identification of sites required for repression of a silent mating type locus in yeast. J. Mol. Biol. 178: 815-834.

Felsenfeld, G. and J.D. McGhee. 1982. Methylation and gene control. Nature 296: 602-603.

Guarente, L. 1988. UASs and enhancers: Common mechanism of transcriptional activation in yeast and mammals. Cell 52: 303-305.

Haber, J.E. and J.P. George. 1979. A mutation that permits the expression of normally silent copies of mating type information in Saccharomyces cerevisiae. Genetics 93: 13-35.

Hoekstra, M.F. and R.E. Malone. 1986. Excision repair functions in Saccharomyces cerevisiae recognize and repair methylation of adenine by the Escherichia coli dam. Mol. Cell. Biol. 6: 3555-3558.

Hofmann, J.F.-X., T. Laroche, A.H. Brand, and S.M. Gasser. 1989. RAP-1 factor is necessary for DNA loop formation in vitro at the silent mating type locus HML. Cell 57: 725-737.

Holliday, R. 1987. The inheritance of epigentic defects. Science 238: $163-170$.

Holliday, R. and J.E. Pugh. 1975. DNA modification mechanisms and gene activity during development. Science 187: 226-232.

Johnston, M. and R.W. Davis. 1984. Sequences that regulate the divergent GAL1-GAL10 promoter in Saccharomyces cerevisiae. Mol. Cell. Biol. 4: 1440-1448.

Kalckar, H.M., K. Kurahashi, and E. Jordan. 1959. Hereditary defects in galactose metabolism in Escherichia coli mutants. I. Determination of enzyme activities. Proc. Natl. Acad. Sci. 45: $1776-1786$.

Keshet, E. and H. Cedar. 1983. Effect of CpG methylation on MspI. Nucleic Acids Res. 11: 3571-3580.

Kiss, A. and F. Baldauf. 1983. Molecular cloning and expression in Escherichia coli of two modification methylase genes of Bacillus subtilis. Gene 21: 111-118.

Klar, A.J.S., S. Fogel, and K. McLeod. 1979. MAR1-A regulator of the $H M$ a and $H M \alpha$ loci and Saccharomyces cerevisiae. Genetics 93: 37-50.

Klar, A.J.S., J.N. Strathern, and J.B. Hicks. 1981. A positioneffect control for gene transposition: State of expression of yeast mating-type genes affects their ability to switch. Cell 25: $517-524$.

Levitt, A., R. Axel, and H. Cedar. 1979. Nick translation of active genes in intact nuclei. Dev. Biol. 69: 496-505.

Lohr, D. and J.E. Hopper. 1985. The relationship of regulatory proteins and DNasel hypersensitive sites in the yeast GAL110 genes. Nucleic Acids Res. 13: 8409-8423.

Lowary, P.L. and J. Widom. 1989. Higher-order structure of Saccharomyces cerevisiae chromatin. Proc. Natl. Acad. Sci. 86: 8266-8270.

McGhee, J.D. and G.D. Ginder. 1979. Specific DNA methylation sites in the vicinity of the chicken $\beta$-globin gene. $\mathrm{Na}$ ture 280: 419-420.

Meyhack, B., W. Bajwa, M. Rudolph, and H. Hinnen. 1982. Two yeast and phosphatase structural genes are the result of a tandem duplication and show different degrees of homology in their promoter and coding sequences. EMBO $/$. 1: 675680.

Mylin, L.M., P.J. Bhat, and J.E. Hopper. 1989. Regulated phosphorylation and dephosphorylation of GAL4, a transcriptional activator. Genes \& Dev. 3: 1157-1165.

Nakayama, N., A. Miyajima, and K. Arai. 1985. Nucleotide sequences of STE2 and STE3, cell type-specific sterile genes from Saccharomyces cerevisiae. EMBO J. 4: 2643-2648.
Nasmyth, K.A. 1982. The regulation of yeast mating-type chromatin structure by SIR: An action at a distance affecting both transcription and transposition. Cell 30: 567-578.

Nasmyth, K.A., K. Tatchell, B.D. Hall, C. Astell, and M. Smith. 1980. Physical analysis of mating-type loci in Saccharomyces cerevisiae. Cold Spring Harbor Symp. Quant. Biol. 45: 961-981.

Nogi, Y., K. Matsumoto, A. Toh-e, and Y. Oshima. 1977. Interaction of super-repressible and dominant constitutive mutations for the synthesis of galactose pathway enzymes in Saccharomyces cerevisiae. Mol. Gen. Genet. 152: 137-144.

Paroush, Z., I. Keshet, J. Yisraeli, and H. Cedar. 1990. Dynamics of demethylation and activation of the $\alpha$-actin gene in myoblasts. Cell 63: 1229-1237.

Perez-Ortin, J.E., E. Matallana, and L. Franco. 1989. Chromatin structure of yeast genes. Yeast 5: 219-238.

Proffitt, J.H., J.R. Davie, D. Swinton, and S. Hattman. 1984. 5-Methylcytosine is not detectable in Saccharomyces cerevisiae DNA. Mol. Cell. Biol. 4: 985-988.

Razin, A. and A.D. Riggs. 1980. DNA methylation and gene function. Science 210: 604-610.

Rine, J. and I. Herskowitz. 1987. Four genes responsible for a position effect on expression from $H M L$ and $H M R$ in Saccharomyces cerevisiae. Genetics 116: 9-22.

Rine, J., J.N. Strathern, J.B. Hicks, and I. Herskowitz. 1979. A suppressor of mating-type locus mutations in Saccharomyces cerevisiae: Evidence for and identification of cryptic mating-type loci. Genetics 93: 877-901.

Rubin, G.M. 1974. Three forms of the $5.8 \mathrm{~S}$ ribosomal RNA species in Saccharomyces cerevisiae. Eur. I. Biochem. 41: 197-202.

Saluz, H.P., J. Jiricny, and J.P. Jost. 1986. Genomic sequencing reveals a positive correlation between the kinetics of strand specific DNA demethylation of the overlapping estradiol/ glucocorticord receptor binding sites and the rate of avian vitellogenin mRNA synthesis. Proc. Natl. Acad. Sci. 83: 7167-7171.

Sherman, F., G.R. Fink, and J.B. Hicks. 1983. Methods in yeast genetics: A laboratory manual. Cold Spring Harbor Laboratory, Cold Spring Harbor, New York.

Southern, E.M. 1975. Detection of specific sequences among DNA fragments separated by gel electrophoresis. I. Mol. Biol. 98: 503-517.

Sprague, G.F., Jr., R. Jensen, and I. Herskowitz. 1983. Control of yeast cell type by the mating type locus: Positive regulation of the $\alpha$-specific STE3 gene by the MAT $\alpha 1$ product. Cell 32: 409-415.

Terleth, C., C.A. van Sluis, and P. vande Putte. 1989. Differential repair of UV damage in Saccharomyces cerevisiae. $\mathrm{Nu}$ cleic Acids Res. 17: 4433-4439.

Weintraub, H. 1985. Assembly and propagation of repressed and derepressed chromosomal states. Cell 42: 705-711.

Weintraub, H. and M. Groudine. 1976. Chromosomal subunits in active genes have an altered conformation. Science 193: 848-856.

Wilks, A.F., P.J. Cozens, I.W. Mattaj, and J.-P. Jost. 1982. Estrogen induces a demethylation at the $5^{\prime}$ end region of the chicken vitellogenin gene. Proc. Natl. Acad. Sci. 79: 42524255. 


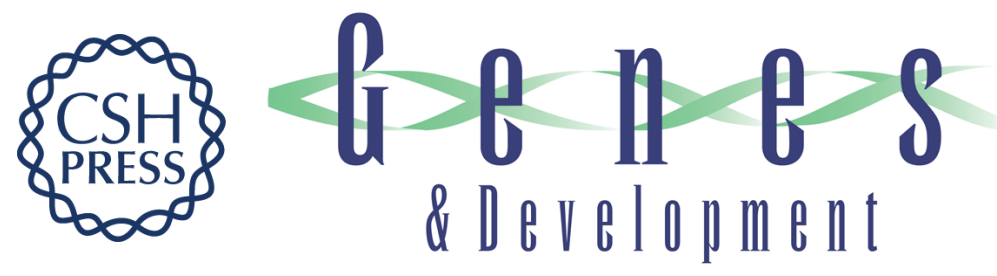

\section{Active genes in budding yeast display enhanced in vivo accessibility to foreign DNA methylases: a novel in vivo probe for chromatin structure of yeast.}

J Singh and A J Klar

Genes Dev. 1992, 6:

Access the most recent version at doi:10.1101/gad.6.2.186

References This article cites 42 articles, 16 of which can be accessed free at: http://genesdev.cshlp.org/content/6/2/186.full.html\#ref-list-1

License

Email Alerting Service

Receive free email alerts when new articles cite this article - sign up in the box at the top right corner of the article or click here.

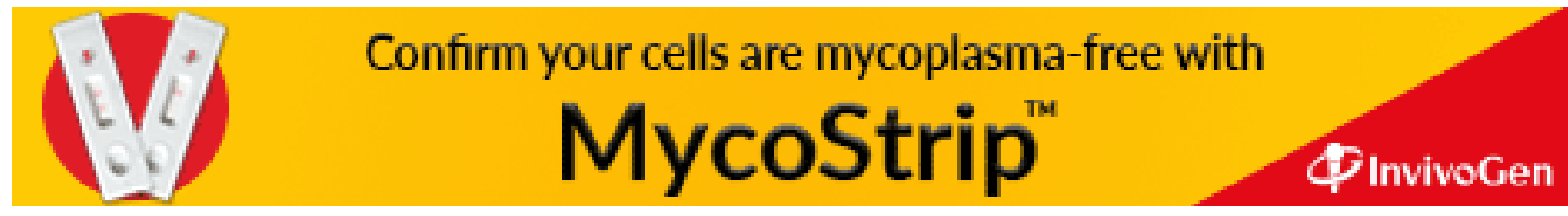

